$$
\begin{aligned}
& \text { Teens and } \\
& \text { terrifory in } \\
& \text { 'post-conflict' } \\
& \text { Belfast }
\end{aligned}
$$

\title{
If walls could talk
}

MADELEINE LEONARD 


\section{Teens and territory in 'post-conflict' Belfast}

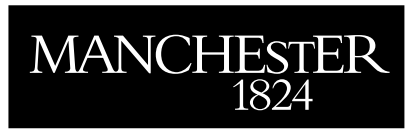

Manchester University Press 
Madeleine Leonard - 9781526120434 Downloaded from manchesterhive.com at 04/26/2023 12:04:07AM via free access 


\section{Teens and territory in 'post-conflict' Belfast \\ If walls could talk}

Madeleine Leonard

Manchester University Press 


\section{Copyright @ Madeleine Leonard 2017}

The rights of Madeleine Leonard to be identified as the authors of this work have been asserted by her in accordance with the Copyright, Designs and Patents Act 1988.

Published by Manchester University Press

Altrincham Street, Manchester M1 7JA

www.manchesteruniversitypress.co.uk

\section{British Library Cataloguing-in-Publication Data}

A catalogue record for this book is available from the British Library

ISBN 9780719096242 hardback

First published 2017

The publisher has no responsibility for the persistence or accuracy of URLs for any external or third-party internet websites referred to in this book, and does not guarantee that any content on such websites is, or will remain, accurate or appropriate.

Typeset by

Servis Filmsetting Ltd, Stockport, Cheshire 